\title{
11. Talking Salvation for the Silent Majority: Projecting new possibilities of modernity in the Australian cinema, 1929-1933
}

\section{Brian Yecies}

This chapter analyses the distinctiveness of the coming of permanent sound (the 'talkies') to the Australian cinema in the late 1920s and early 1930s. The coming of sound resulted in fundamental, but not uniform, change in all countries and in all languages. During this global transformation, substantial capital was spent on developing and adopting 'modern' technology. Hundreds of new cinemas were built; tens of thousands were wired with sound equipment - that is, two film projectors with sound attachments, amplifiers, speakers and electrical motors - and some closed in financial ruin during the Great Depression. The silent period ended and sound became projected as a symbol of progress in the metropolis and beyond. As Nowell-Smith and Ricci, and Higson and Maltby point out, ${ }^{l}$ this incredible shift was driven principally by Western - in other words, American and European-film producer-distributors who retained a dominant influence because of their individual, and at times common, efforts to 'modernise' their production, distribution and exhibition methods. ${ }^{2}$ The coming of sound, however, also gave rise to the development of local responses to these technological trends. It is the aim of this study to show how the 'global' transition was more local than previously thought, challenging conventional assumptions about global and local business interests in the cinema industry.

The coming of sound to the Australian cinema was pioneering and exuberant, and attitudes towards the so-called new medium were bold. The case studies of the most active of Australia's sound pioneers are presented here in order to illuminate the larger processes concerning the ambivalent embrace of modernity in Australia. Australian inventors and American electrical companies employed by the major Hollywood studios each espoused a different agenda in the promotion of their sound-projection technology. ${ }^{3}$ I suggest that Film Weekly and Everyones - Australia's major film industry trade magazines at the time-promoted the coming of the talkies as a technological battle. They leave us with the impression that Australians were underdogs in some kind of 'talkie war', pushing an agenda of resistance against the perceived Americanisation of modernity in Australia. Opposition revolved mainly around Western Electric's plans to wire major city cinemas with American technology while preventing competition from local competitors. ${ }^{4}$ 
This confrontation spawned one of the many changes in the spheres of cinema and entertainment, which, according to Jill Julius Matthews, 'scattered the sparks of modernity into everyday life' ${ }^{5}$ The cost of the Western Electric system - one of the only commercially viable sound systems available in Australia in late 1928 and early 1929 - remained, however, out of reach for a majority of independent, suburban and country cinemas. ${ }^{6}$ The minimum cost of installing Western Electric sound equipment in Australia was put at between $£ 6,000$ and $£ 7,000$, which did not include the weekly fees in the company's compulsory 10 -year service contracts (estimated to cost up to an additional $£ 4,000$ ). ${ }^{7}$

In response to a lack of practical and affordable choices, a wide range of Australian tinkerers, electricians, engineers, radio and wireless specialists and entrepreneurs developed their own sound systems and/or adapted acquired technology in order to bring sound to as many cinemas as possible. The geographical specificity of these producers highlights the tension between viable local and foreign technology as sound was spread across Australia's vast distances.

The US film industry in the middle to late 1920s, according to Gomery, embraced sound technology primarily for economic reasons, ${ }^{8}$ although it could have been that the Australian film industry had little choice in the matter. Australia's largest exhibition chains committed ambitious investments to convert to sound with US companies in order to screen Hollywood films. That is to say, the distribution side of the Australian film industry was dominated largely by American interests, making the Australian market one of the largest sources of foreign film revenues for major Hollywood studios and their producer-distributors. When the local distribution exchanges of Fox, First National-Warner Bros., FBO-RKO, MGM and Paramount - all controlling members of the Motion Picture Distributors Association (MPDA) of Australia-began regularly adding sound films (that is, all-talkie, part-talkie and films with sound effects, asynchronous and/or synchronous music) to their catalogues in 1929, it seemed as though the conversion to sound was inevitable, at least initially for capital cities. ${ }^{9}$ At the same time, Western Electric and the powerful members of the MPDA of Australia appeared to thwart competition at all costs. Therefore, Australian sound companies and inventors developed strategic methods and alliances in order to meet international and domestic competition head-on.

\section{Australia's 'talkie war'}

The concept of marrying sound and pictures in Australia had been around since the start of cinema. The coming of sound was not a new phenomenon, as many popular accounts would have it. Collins proposes that the Australian cinema was never silent - 'some form of sound accompaniment dates back to the origins of moving pictures'. ${ }^{10}$ Live musical performances enhanced the cinematic 
experience, creating extra value for spectators, though mechanically reproduced sound eventually became cheaper than an orchestra, especially for the larger city cinemas. Until the late 1920s, sound technology developed outside the Hollywood studio system was promoted as a temporary and novel attraction. Yet, the Australian cinema experienced a new beginning in late 1924 when entrepreneurial picture showmen imported and endorsed American De Forest Phonofilms' sound-on-film projection equipment. Until this time, projecting silent films with live accompanying music or recorded music and dialogue on large phonograph discs was the most common method of presenting a sound film.

De Forest Phonofilms Australia Ltd (Phonofilms Australia), a sound company operating independently of the Hollywood majors, was formed in August 1925 (first through American Phonofilms and then through British Phonofilms). ${ }^{11}$ As Figure 1 illustrates, the company promoted its novel system as the ultimate sign of modernity: 'One of the most amazing achievements of the age' — aiming to build a local franchise and to have its technology adopted. As seen in other trade advertisements, Phonofilms Australia wanted exhibitors and industry people to know that it was leading the 'dawn of a new era in the industry'. ${ }^{12}$

American distributors did not appreciate alternative and ambitious efforts to modernise Australia with sound technology outside the Hollywood studio system. As I have written in more detail elsewhere, it was Phonofilms Australia to which the Australian press attributed the instigation of the talkie war. ${ }^{13}$ Headlines in the trade magazines screamed: "War of "Talkies" Looms as Phonofilms Issue Warning.' 14 The general managers of Phonofilms Australia had threatened legal action against anyone using a sound-on-film process that infringed Phonofilms' rights in Australia. ${ }^{15}$ Nevertheless, a host of local competitors soon attempted to challenge Phonofilms. Suffice to say that the De Forest Phonofilms Company advanced the experimentation of film sound technology and the acceptance of that technology in Australia by setting the stage for modernity and the further adoption of sound innovations.

Building on this Phonofilms Australia narrative is the arrival in Australia in November 1928 of sales and service engineers from Western Electric-ERPI, who came to wire simultaneously the Hoyts Theatres' Sydney Regent (with Fox Movietone brand sound-on-film equipment) and the Union Theatres' Sydney Lyceum (with Vitaphone brand sound-on-disc equipment). The public had the greatest opportunity to experience (to see and hear) urban modernity at Union Theatres' and Hoyts Theatres' flagship cinemas because this was where the industry's changes first occurred. 


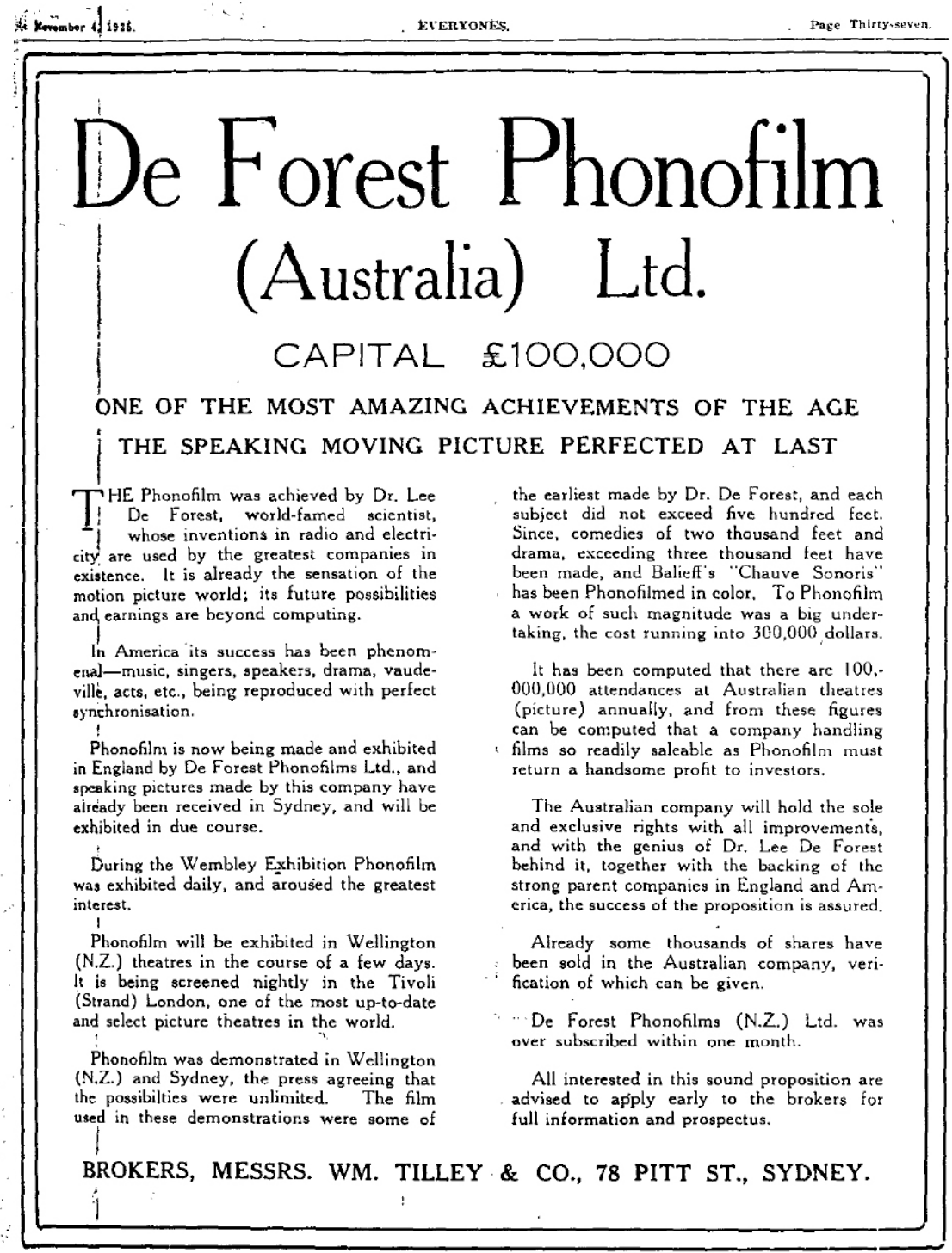

\section{Figure 1}

Source: Advertisement, De Forest Phonofilms Australia, Everyones, 4 November 1925, p. 37. Reprinted by permission of the National Library of Australia.

In late December 1928, Warner Bros.' The Jazz Singer premiered at Union Theatres' Lyceum and Fox's The Red Dance premiered at Hoyts' Regent, sending shock waves through Sydney and the whole of the film industry. According to reports in Everyones and Film Weekly, the age of sound arrived in a 'big way'. ${ }^{16}$ In one week, the Lyceum and Regent combined took between $£ 8,000$ and $£ 8,500$ - breaking all records and unexpectedly selling out all shows. ${ }^{17}$ 
According to the trade papers, talkies had rejuvenated public interest in motion pictures and rescued the film industry from its pre-Depression era slump. ${ }^{18}$

Suburban exhibitors immediately began wondering how soon they could convert to sound and modernise their programs. Acting as the 'voice' of the Australian film industry, however, Stuart Doyle, the managing director and primary spokesman of Union Theatres Ltd - and powerful manager of Australasian Films Ltd-pragmatically cautioned exhibitors about the future of talkies in the suburbs:

No theatre can show talking pictures profitably unless it can take from $£ 1,200$ to $£ 2,000$ a week; and unless some method is devised to cut down the cost of equipment, reproducing records and particularly the terrific cost of maintenance, talkies are a commercial impossibility for suburban and small town shows. ${ }^{19}$

So suburban and country exhibitors waited, but not for long.

In mid-1929, the talkie war campaign resumed in the trade papers when the American RCA Photophone and a few Australian sound systems - such as Raycophone, Australtone, Markophone and Auditone - entered the field and began competing with Western Electric for installation contracts and equipment leases and sales. ${ }^{20}$ The talkie war, which had started in 1927 with Phonofilms Australia, had not been forgotten.

In Australian film history - and probably in that of many other countries - there remains a dearth of information surrounding the coming of sound. Previous studies provide brief summaries of activities between late 1928 and mid-1929, while giving scant attention to the details surrounding entrepreneurial efforts before and after this time. ${ }^{21}$ Shirley and Adams stress that Australian exhibitors converted to sound in order to survive as 'new pioneers' attempted 'to break the [US] monopoly' by developing sound recording and projecting equipment of their own. ${ }^{22}$ Tulloch presents the idea of a hierarchical reaction to the apparent American dominance of sound technology, which was 'itself a hierarchy established in, and exported from, the USA'. ${ }^{23}$ Walsh's more recent work stands apart by offering an examination of the opposing relationships between distributors and exhibitors, entertainment moguls, manufacturers and users of technology, as well as industry and government. ${ }^{24}$ He indicates that there was more than a simple American monopoly during the transition; Hollywood did not wield 'ruthless power' over Australia. Walsh coins the phrase 'frenzy of the audible', which captures the spirit of modernity in Australia as some kind of sound technology became part of the exhibition experience before, during and after the 1920s. ${ }^{25}$ With these studies in mind, it is unmistakable that Hollywood's efforts in the export (transfer) of US technology and infrastructure for sound 
came to a head in 1929-'a year of sound and fury', which proved that 'silent cinema was doomed'. ${ }^{26}$

\section{Preventing extinction of the Australian enterprise}

Primary research coalesced in Figure 2 shows at least 67 Australian sound systems that challenged the apparent American dominance. The geographical rise and development of these alternative sound systems is noteworthy because it suggests that sound technology was spread by a multitude of sound companies, engineers, tinkerers and theatre and cinema entrepreneurs. Despite the portrayal in the trade press of Hollywood film distributors as military victors in a so-called war to wire Australia with American technology, these Australians invigorated - that is, mediated - modernity throughout a vibrant period of sound experimentation. Not all initiatives were successful, but clearly the demand for sound was heard all over Australia.

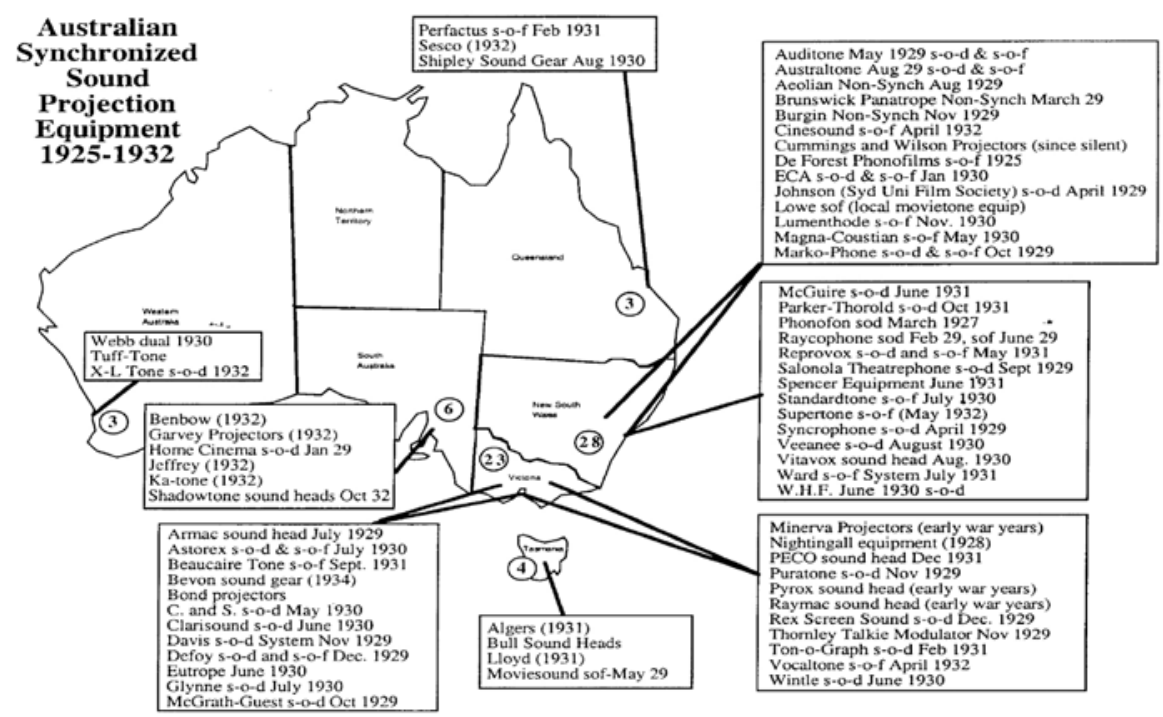

\section{Figure 2}

Source: Derived from articles and advertisements found in Film Weekly and Everyones between 1925 and 1932.

The Raycophone case exemplifies how at least one eminent Australian system achieved 'national' status through the strategic reactions to the importation of American sound technology. The Australian-made Raycophone ('Rayco' from its inventor, Raymond Cottam Allsop's, name and 'phone' from its inclusion of disc technology) outperformed and outlived all other Australian-made sound systems. Allsop's survival strategy began with price-promising a dual-disc and sound-on-film system for a 'revolutionary' cost of $£ 1,500 .{ }^{27}$ Raycophone was given several stealthy trade demonstrations in early February 1929, and 
was first demonstrated publicly on 10 June $1929 .^{28}$ The company's take-over in April 1930 by Harringtons Ltd — an Australian photographic (and later film) equipment supplier and distributor since 1899 and a radio supplier since the inception of the industry in 1888 - further ensured its survival by increasing Raycophone Ltd's manufacturing and engineering talent, enlarging its sales and distribution potential and infusing financial resources into Allsop's regional sound company. ${ }^{29}$ Its success was due to the company's political and film industry ties, which led ultimately to its 24 per cent market penetration. As of June 1937, 345 Raycophone sound-projection systems were installed and serviced in Australia, ${ }^{30}$ demonstrating that the coming of sound to the Australian cinema was facilitated directly by employing Australian technology and Australian engineering as much as it was by American technology. ${ }^{31}$

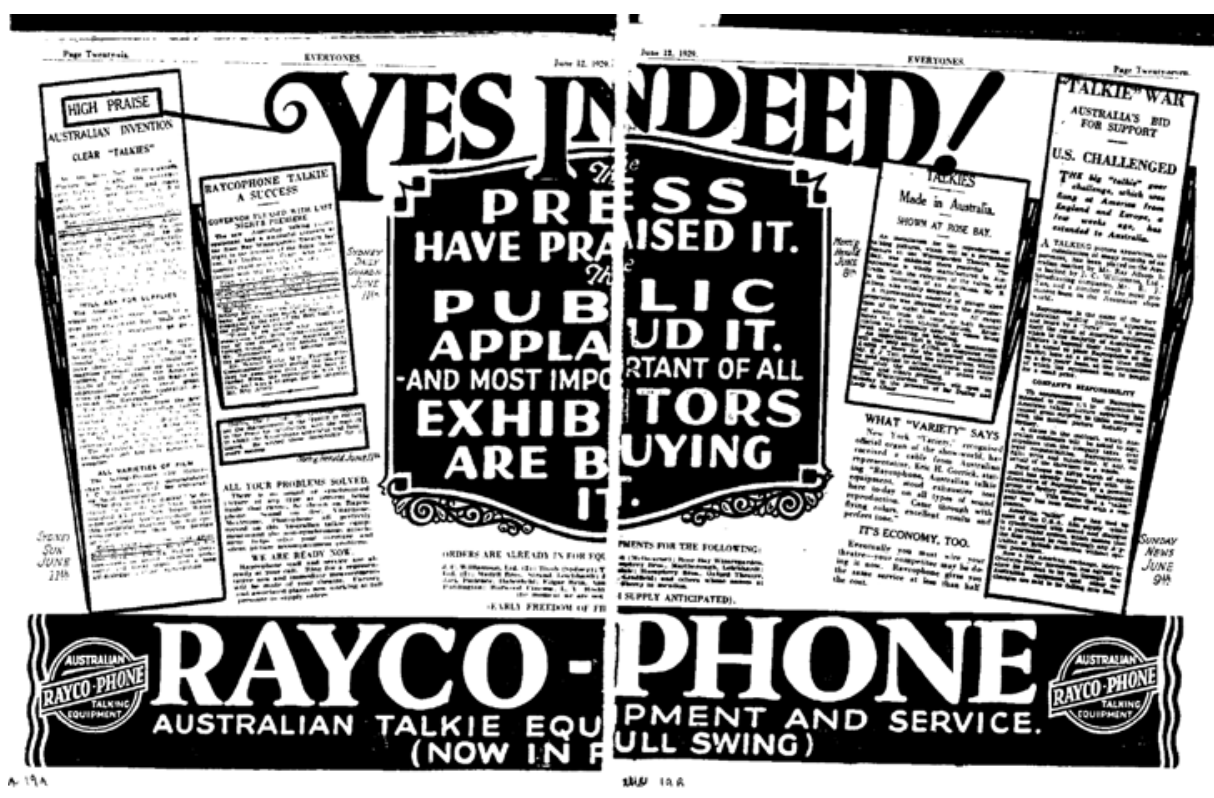

\section{Figure 3}

Source: Advertisement, Raycophone, Everyones, 12 June 1929, pp. 26-7. Reprinted by permission of the National Library of Australia.

After the launch of Western Electric's sound-projection system in Australia in November 1928, Allsop began developing a mechanism for projecting sound films in an auditorium, using amplifiers and loudspeakers. ${ }^{32}$ Yet, as a radio pioneer and prominent Sydney electrician, he saw the likelihood of the advent of motion picture sound in Australia well before Western Electric-ERPI representatives set sail for the region. Allsop was an electrician in charge of designing and building transmitters for 2BL, which was a New South Wales radio station owned by Broadcasters-Sydney Ltd-one of the earliest radio stations to go to air in Australia, in November $1923 .^{33}$ According to his own 
testimony in an ABC radio interview in 1970, Allsop had begun developing sound-film technology in the early 1920s in experiments that were extensions of his radio knowledge. As early as 1921, Allsop claimed to have successfully synchronised a wax cylinder recording with a motion picture film, and there is no reason to doubt him. Allsop had also produced four short synchronised vaudeville films - shot in the old 2BL radio studio overlooking Market Street in Sydney - in order to prove the capabilities of his disc system. ${ }^{34}$ Allsop ceased his sound-film experiments after 1921, however, primarily because of limitations in audio amplification.

When Allsop resumed his experiments seven years later in June 1928, there seemed to be one key reason for him getting back into sound: Warner Bros.' success with The Jazz Singer in October 1927. By this time, the development of efficient loudspeaking mechanisms and improvements in audio amplifiers significantly enhanced the profitability of the talkies in the United States. In addition, there were 28 American talkie features in Australia in early January 1929 and only three cinemas wired for sound. ${ }^{35}$ Furthermore, in early February 1929, headlines declared, 'Talkie field now open for all quality sound devices', which was in response to Western Electric's (interchangeability) decision in the United States to allow competing systems - which Western Electric put through a rigorous approval process - to project Hollywood films. ${ }^{36}$ In this way, Allsop and many other Australians had more than ample motivation to perfect an Australian-made sound-projection system.

Raycophone's supporters and company sponsors were a network of influential political contacts and well-known theatre and cinema entrepreneurs - basically friends in high places whom Allsop exploited for obvious reasons. The list includes the Australian entertainment moguls J. C. Williamson Ltd, Keith Murdoch (media tycoon Rupert Murdoch's father), the Tait brothers, Farmer \& Co. Ltd and the NSW Broadcasting Company (NSWBC), which represented an influential association of Australian media organisations. The Williamson-Tait group was connected with Allan and Company (music distributors) and Buckley and Nunn Ltd (radio and amplification equipment retailers). ${ }^{37}$ Murdoch brought invaluable support to the Raycophone organisation from his Herald and Weekly Times, publishers of the Sydney Morning Herald, the Sun and Telegraph Pictorial. ${ }^{38}$ This web of interrelated connections extended throughout the Australian motion picture and entertainment industries, linking Raycophone to Western Electric, Union Theatres and Movietone, via Hoyts Theatres.

Australian systems competed with one another in addition to international representatives. For example, in mid-1929, the Australtone sound company claimed that it planned to produce a series of short sound films in order to supply its installation clients with continuous entertainment. ${ }^{39}$ Australtone began as a disc system, and was first demonstrated publicly to industry representatives 
and newspapermen in the Queen's Theatre in Crow's Nest in Sydney on 31 July 1929. This was about seven weeks after industry magazines claimed that the talkie war had been declared in Sydney, with Raycophone in the field. William J. Tighe was the young ambitious engineer credited with inventing Australtone and synchronising its pictures, which the press coverage indicated was an insurmountable challenge in the face of Western Electric's market strength and overall wiring plans for Australia. ${ }^{40}$ Tighe's system was under great pressure to prove that it could handle disc films with the same level of quality as that of Western Electric's Vitaphone, as well as Raycophone. A series of 12 talking films referred to as 'local favourites', made by the 'world-class' cinematographer Arthur Higgins, were used to debut the disc system along with pre-recorded music. Higgins had filmed the pictures for Australtone while Tighe innovated the system during the first half of 1929. His reputation was used to help launch Australtone as a world-class producer of sound films. ${ }^{41}$

While Allsop took about four months of canny planning and publicity as well as sound engineering to attract the financial backing and support needed to launch Raycophone as a competitor to Western Electric, Tighe and his relative Lewis C. Tighe, an advertising specialist, appeared to do the same in four weeks with Australtone. Australtone quickly rose in the shadow of Raycophone, but it then experienced a swifter fall.

Unlike Raycophone, Australtone did not have friends in high places. Apart from minor quality concerns, a lack of influential connections inside and outside the film industry hindered its potential to offer viable long-term solutions to smaller suburban and country exhibitors. Although the Tighes promoted Australtone as the 'salvation of suburban men', American film distributors refused to supply the system with their sound films and boycotted it in late 1929. ${ }^{42}$ This dispute manifested itself as exhibitors protested the huge expenses involved in wiring their cinemas with American sound equipment (see Figure 4). As a result of the boycott, Australtone began looking to South Australia and Western Australia, where a delay in the coming of sound provided additional opportunities for installation contracts - particularly for disc equipment. At the end of 1930, South Australia reportedly had the highest percentage of disc installations - 30 out of a total of 54 (56 per cent) - while Western Australia had 26 disc-only and 14 dual projectors, reflecting the nature of experimentation in those states as much as the distribution speed of disc equipment. ${ }^{43}$ Although Australtone disappeared by 1933, its story is symbolic of the complexities of the diffusion of the coming of sound to the Australian cinema and the cutthroat competition that existed between Australian-made and international equipment. 


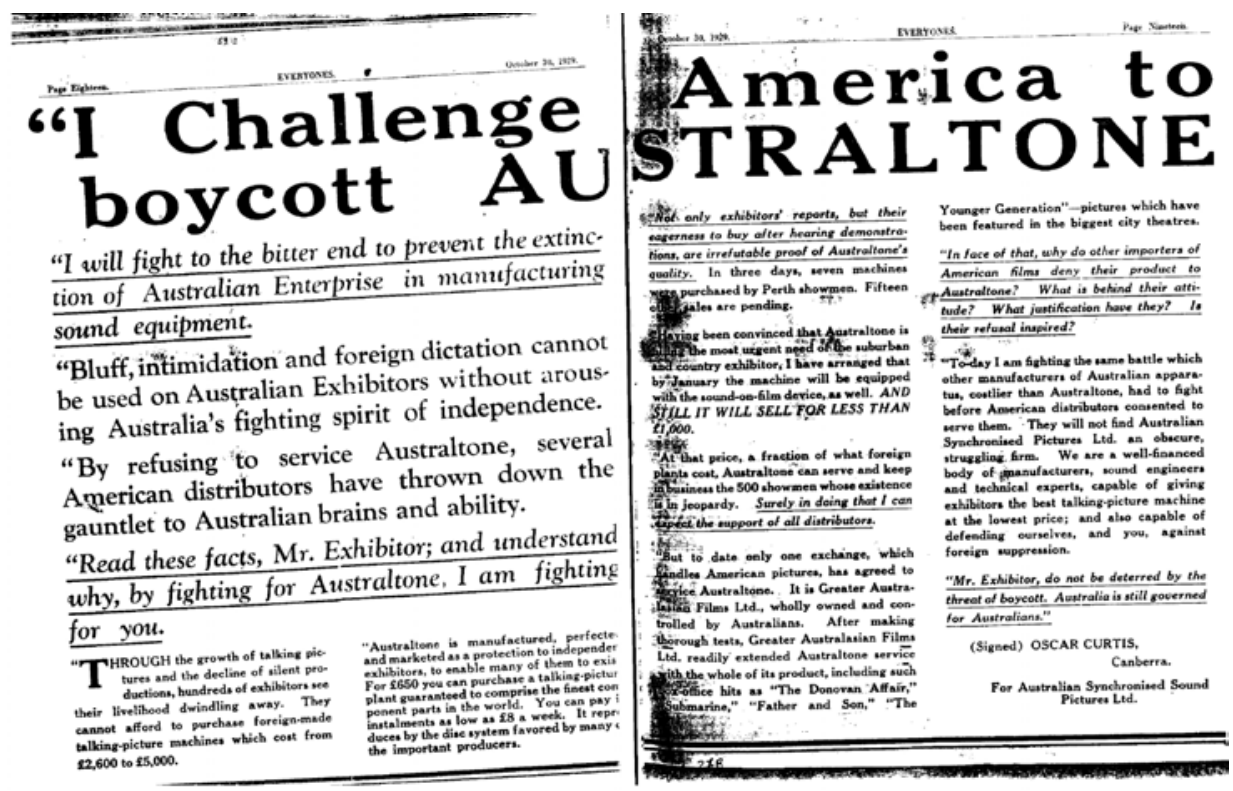

\section{Figure 4}

Source: Advertisement, Australtone-Australian Synchronised Sound Pictures, Everyones, 30 October 1929, pp. 18-19. Reprinted by permission of the National Library of Australia.

While Raycophone and Australtone began their installation campaigns in NSW, the Australian-made and 'all-Australian talkie gear' Markophone dual-disc and sound-on-film system was publicised heavily to Victoria's regional exhibitors in 1929 and 1930. By the beginning of August 1929, Western Electric-ERPI had installed equipment in only 13 of Victoria's estimated 107 cinemas $^{44}$-hence the market seemed wide open for competition. Promoters endeavoured - as with nearly all other sound systems - to publicise and demonstrate Markophone (as seen in Figure 5) in advance of its availability, creating awareness and interest in regional Victoria, which flowed into NSW.

Adaptability to existing silent projection equipment was one of Markophone's key features. According to company records, Markophone was a 'sound head' and 'synchronised disc attachment plan' created by Hoyts Theatres' cinema executives Leon Samuel Snider, Edward Lewis Betts and Alexander Henry Noad - investors in the system. Snider, Betts, Noad and Betts' brothers (Edward, George and Frederick) were also large Hoyts shareholders. The names of Snider, a well-known exhibition capitalist, and the Betts family, well-known NSW exhibitors since before 1920, added a significant contribution to Markophone Ltd because of their ties to Hoyts. ${ }^{45}$ This support from Hoyts Theatres Ltd executives - including engineering support from Hoyts technicians - helped disseminate Markophone until the mid-1930s, meaning it survived significantly longer than most other Australian sound systems. ${ }^{46}$ The company eventually 
folded in the mid-1930s, when most cinemas had been wired for sound. Apparently, the company had fulfilled its central aim of servicing the transition to sound.

THE MOST COMPACT AND MECHANICALLY PERFECT AUSTRALIAN EQUIPMENT THAT CAN COMPETE WITH ANY IMPORTED SYSTEM AND THE ONLY AUSTRALIAN TALKIE EQUIPMENT THAT EMBODIES STANDARD ENGINEERING PRINCIPLES.
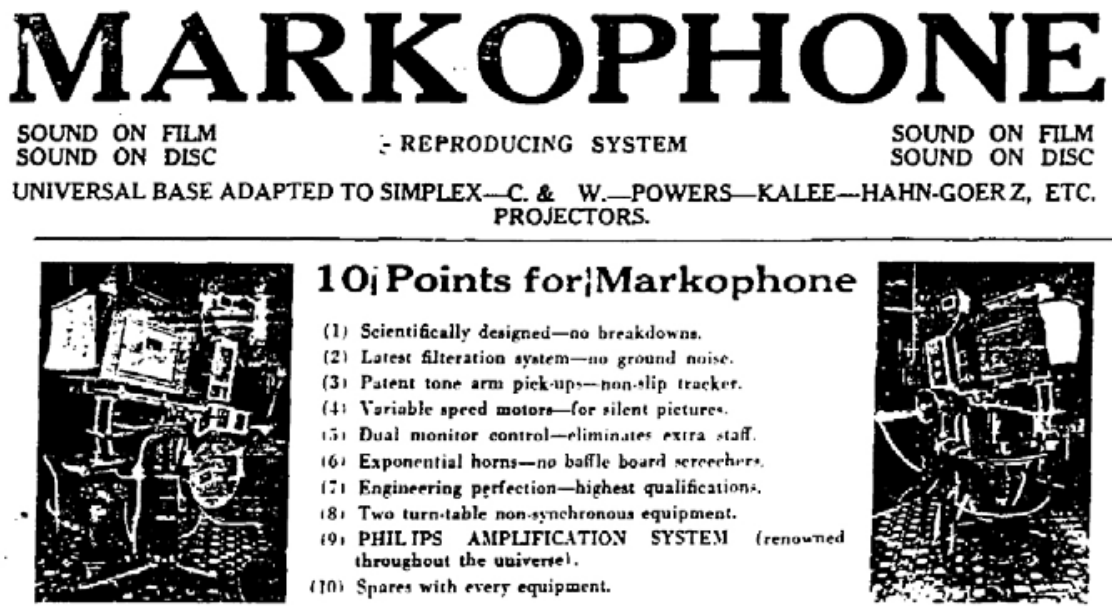

\section{0j Points foriMarkophone}

(1) Scientifically designed-oo breakdowns.

(2) Latest filteration system-no ground noise

(3) Patent tone arm piek-up,-nan-9lip trackef.

(t) Veriable speed motors-for silent pietures.

1.i) Dual monitor control-rliminutes extra staff

16. Exponential horns-no baffle bodrd sereechrr.

(7) Engineering perfection-highest qualification:.

18, Two turn-table non-synchronous equipment.

19, PHIL.IPS AMPLIFICATION SYSTEM irenowned throughout the universel.

(10) Spares with every equipment.

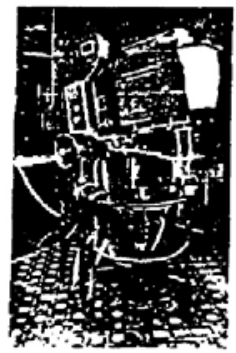

$\mathrm{M} \mathrm{A} \mathrm{R} \mathrm{K} \mathrm{O}$

THE.ITRE ROYAL, WEST RYDE, N.S.W.;

PAR AHULNT THEATRE. MORTDALE, N.S.W.

P.IL.A.E THE.TTRE. RYDE. N.S.W.: NATIONAI

THEATRE. RICH UONO, VIC

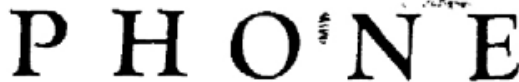

LOCO THEATRE, NORTH MELBOURNE, VIC. CITY COUNCII. THEATRE. WILLLAYSTOW: VIC. ST. GEORGE THE.ITRE, YARRAVILLE.
VIC.

AND THE SAVOY (LATE ADYAR HALL) SYDNEY

OPENS THIS MONTH FOR CONIINUOUS TALKIES WITH MARKOPHONE MORE THAN 20 MARKOPHONE EQUIPMENTS WILL BE INSTALIED BY END OF JULY.

PRICE £1450 PRICE $£ 1450$ TERMS FROM $£ 100$ DEPOSIT. BALANCE OVER TWO OR THREE YEARS.

WE SELL-NOT LEASE-IT BECOMES AN ASSET OF THE THEATRE. E50 WILL COVER WIRING. SCREEN FRAME. INSTALLATION. ETC IF YOU HAVE A NON.SYNCHRONOUS SET WE WHL MAKE A REASONABLE ALLOWANCE.

\section{NOE SERVICE SERVICE ${ }_{\mathrm{FEE}}^{\mathrm{NO}}$}

Sound experts agree that an operator after two weeks tuition is efficient in adjustment of minor defects of not only Markophone but any talkie equipment-Why a set service fee? Our service staff at all hours available periodical inspections. MARKOPHONE IS FOOL PROOF-Pay for Service You Require and Receive. MARKOPHONE LTD., 521 George St.. SYDNEY. London Stores Building, MEL_EOURNE.

\section{Figure 5}

Source: Advertisement, Markophone, Everyones, 4 June 1930, p. 49. Reprinted by permission of the National Library of Australia. 
Finally, between 1929 and 1931, Phonofilms Australia inspired another Australian sound system: the Auditone, and its many incarnations. ${ }^{47}$ Charles Ward, a radio engineer from New Zealand who gained valuable training and experience working on the De Forest Phonofilms system in 1925, developed the Auditone in conjunction with Stanley William Hawkins, the entrepreneur who managed Phonofilms Australia in 1927. ${ }^{48}$ Auditone was demonstrated, promoted and recast several times as a new system (with names such as First British, Ward and 'Lumenthode-Beam Projection and Sound Apparatus'), yet failed as a result of tough competitive tactics by Western Electric. The alternative equipment showed promise by gaining a number of installation contracts, but it lost its major sponsor towards the end of 1929 when Broadway Theatres, a regional chain of cinemas, cancelled its Auditone contracts. ${ }^{49}$ As a result of these losses, Auditone Ltd lost a significant window of opportunity before the onset of the Great Depression, which surely played a role in its liquidation proceedings in $1931 .^{50}$

Despite what Australian histories tell us, inventors across the nation moved local manufacturing forward by pooling talents, wireless and phonography expertise, entrepreneurial visions and scientific research, forming an active national sound-film industry. The existence of many of the Australian sound companies and alternative systems pictured in the map in Figure 2 were based first on the level of investment capital used to finance new wiring and equipment manufacturing ventures, and second on the cost of the equipment. Outdated (or unwanted) technology could be sold off to smaller, suburban and rural cinemas as larger city cinemas upgraded to newer models, which became competitive advantages against other systems and exhibitors. This is a critical point because the cinemas that could not afford the latest sound technology used disc systems for much longer than most city venues in order to save money. For all of these reasons, the transition to sound was an uneven process, which took place in a seemingly unorganised way.

After 1929, Western Electric and RCA continued to wire a majority of the larger metropolitan and suburban cinemas, replacing many of the Australian systems identified in the map in Figure 2 that did not meet 'American quality standards'. These systems were eventually thrown on what the trade press frequently called the scrap heap. In short, by 1937, all of Australia's cinemas had been wired, ${ }^{51}$ and all of the Australian-made systems had perished except for the Raycophone, which lasted well into the 1950s.

\section{'Quality' of local, regional and national ingenuity}

Ostensibly, the coming of sound seems to have facilitated Hollywood's dominance of English-speaking countries, raising sharp issues about the promotion and protection of foreign versus local interests. It is true that between 1929 and 1932 Australians utilised a combination of new and improved disc and sound-on-film 
systems as a means of circumventing US patent monopolies. Rather than group all Australian sound-reproducing equipment into one category, however - as the film industry trade papers did with the terms 'local' and 'locally made' - it might be more productive to think about this history more diversely in terms of local, regional and national specificity.

A range of Australian-made sound projectors appeared as near copies of existing systems with little chance of a successful patent application, or an imported system promoted as a local product. Projection technology, then, was customised and modified (adapted) on a local level by local engineers after arriving at the installation location. Local systems can be defined as backyard innovations and one-off adaptations assembled for use in schools, country town halls, churches and travelling shows. Country-based systems were made from scratch — primarily in the disc format - representing the cheapest ways to exhibit sound films. Some were promoted by smaller, often fly-by-night organisations. All were alternatives to the dominant Western Electric and RCA equipment and to the better-known Australian equipment-Raycophone, Australtone, Markophone and Auditone - combining new and used phonograph and projector parts, motors, gears and belts (rubber and leather), connecting a gramophone player or another type of disc turntable with a silent projector. Designers were usually the operator and sole service/maintenance engineer, since only they knew how the modifications worked. Such people projected for themselves, friends or for managers of smaller venues. One local device called the Dowling Apparatus, which 'causes the gramophone and the film to synchronise exactly', cost as little as $£ 5 .^{52}$ Sadly, little is known about its Mr Dowling and many other pragmatic and opportunistic tinkerers like him.

Creators of so-called locally made or alternative sound-projection systems were under enormous pressure to promote any and all competitive advantages regarding their particular equipment. Claims of local origins were often prominent in public relations articles and advertisements: Wintle, 'Australian Made, 100\% British'; 53 Astorex, 'All Australian Talkie Equipment'; ${ }^{54}$ Beaucaire, 'Made and Patented in Australia'; ${ }^{55}$ and Australtone, 'All Australian Talkie Equipment'. 56 Paradoxically, the above claims attempted to reaffirm the idea of a national sound industry by the inventors or innovators themselves, yet few could secure successful patent applications, which represented a primary avenue for the recognition and protection of national inventions. These clever local concoctions formed the lower levels of a hierarchy of sound equipment in Australia.

'Regional' Australian-made equipment, in comparison, cost more than £5, but was mostly still affordable. Slick trade advertisements promoted installations of disc systems at a cost of $£ 225-300$ for a single apparatus, often omitting prices for a complete system (which was two projectors and two turntables for reel change-overs) and making prices appear more attractive. As seen in Figure 6, 
Bert Cross and Arthur Smith's Cinesound sound-on-film system was advertised 'from $£ 225^{\prime}{ }^{57}$ Exhibitors had to double these prices in order to get a complete system.

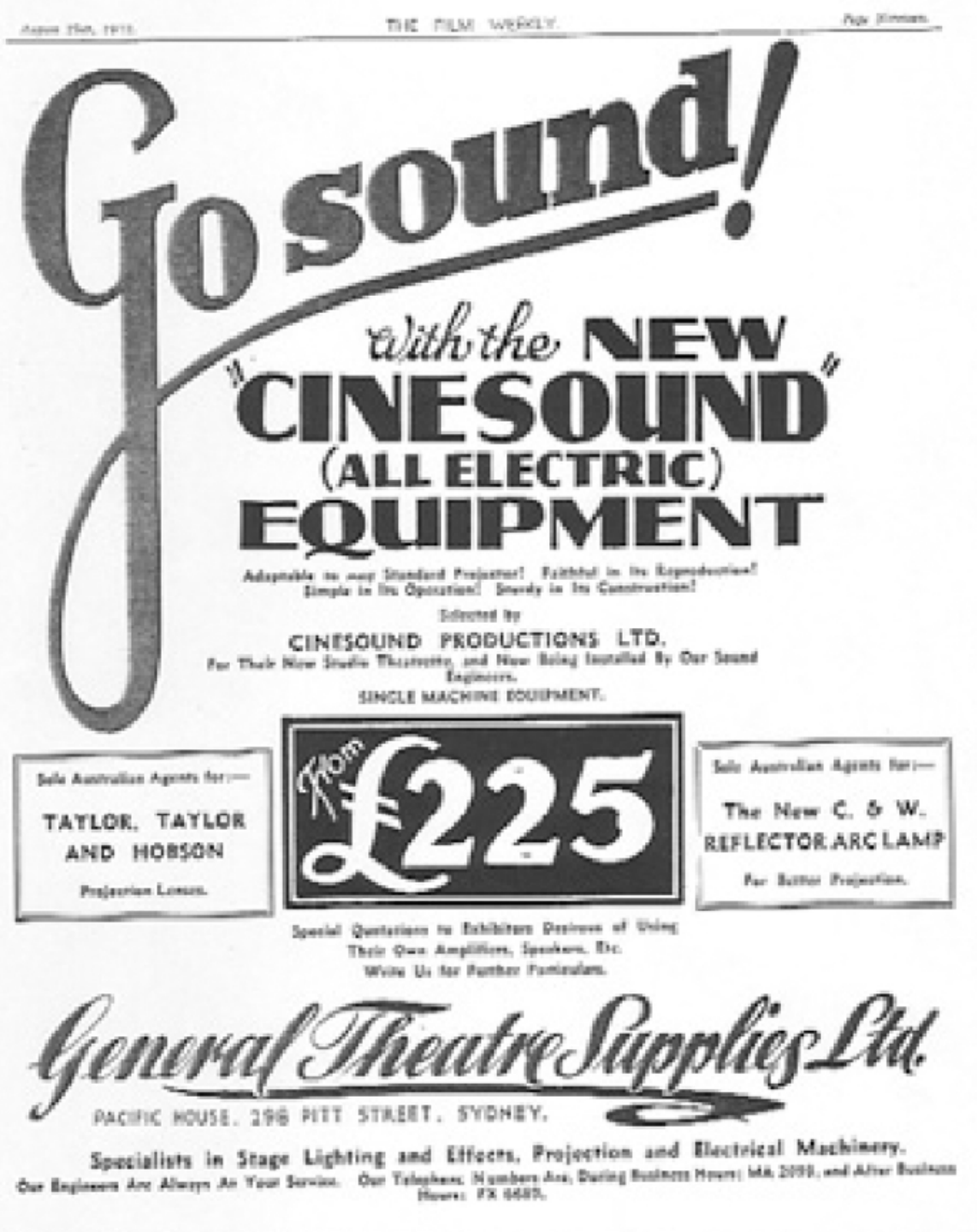

\section{Figure 6}

Source: Advertisement, General Theatre Supplies Ltd-Cinesound, Film Weekly, 25 April 1932, p. 19. Reprinted by permission of the National Library of Australia. 
Regional inventions such as Cinesound were constructed by industrial systems, produced in greater numbers and distributed to several exhibitors and/or multiple installations in cinemas throughout one particular state. They were more durable than local systems because they were often cast in metal. Unlike local sound-on-disc systems, a majority of regional systems offered sound-on-film as well. Not all of a brand's units looked the same, however, because design modifications were necessary due to the diversity of the pre-existing silent equipment to which they were adapted. These systems, which often employed a team of service/maintenance engineers to handle large distribution contracts, made up the middle hierarchy of sound equipment in Australia.

On the whole, Australian sound companies shifted positions in the hierarchy. For example, Auditone Ltd was a regional system until it opened its second sales branch in Brisbane in June 1930, at which point Auditone became a 'national' system. ${ }^{58}$ National systems had an established distribution network in place or soon developed one in order to promote and accommodate interstate sales. In addition, national companies were supported by substantially greater finance capital than regional companies. As indicated earlier, Raycophone became a national system after 1930, when established national photographic and radio supply company Harringtons acquired Allsop's promising regional venture and transformed it into a thriving national institution. Showmen and exhibitors could now inquire about Raycophone equipment and contract information at any of the three locations operated by Raycophone Ltd in Sydney (assembly works, factory or city offices) or at one of Harringtons' many offices in Sydney, Newcastle, Katoomba, Melbourne, Brisbane, Adelaide, Perth and Hobart, as well as in Auckland and Wellington in New Zealand. ${ }^{59}$

As we have seen, Australian sound companies were many and varied. Entrepreneurial individuals, radio amateurs, engineers and electrical enthusiasts and well-organised companies promoted sound-on-disc and sound-on-film projection systems because no one seemed to know which format would become standard. At the same time, US film companies continued to distribute silent films until late 1932 and early 1933 in order to profit from the cinemas still waiting to convert to sound, elongating the industry's complete transformation. The coming of sound to Australia took at least a decade to achieve, and new developments and improvements are being made continually today.

Many of the models pictured and discussed in trade advertisements were created for demonstration purposes in order to judge the system's potential to generate profits for the exhibitor and sound company. For example, the Wintle disc system from Melbourne (as seen in Figure 7), which was known as both Australian-made and ' 100 per cent British', was promoted as a new local product, but never came to fruition because of a lack of exhibitor interest. 
The advertisement below illustrates the confusion and the disorder exhibitors faced during the coming of sound. One trade report of bad sound reproduction could kill any chance of an invention's acceptance, let alone success. The designs and development of many projectors reached only a prototype stage where people could view it because they could not be or were not mass-produced. Yet, installing (and purchasing or leasing) a local, regional or national Australian projection system surely provided a kind of salvation for the suburban exhibitor because it circumvented issues of foreign patent ownership and control, high import duties, royalty fees and Western Electric's mandatory 10-year service plan. Rather than a 'battle', however, there was a notable frenzy of invention, innovation and adaptation during the transition as Australians attempted to project sound films with local technology.

Promotional campaigns for Raycophone, Australtone, Markophone and Auditone emphasised price, ownership and customer testimonials in localised contexts. While trying to survive, however, nearly all systems around the globe either succeeded or failed by living up to or failing to live up to Western Electric's insistence on a particular kind of quality - expressed in the advertising discourse and trade press campaigns run by Western Electric (and RCA, to a lesser degree). Western Electric's arrival, business strategies and intense promotional efforts can be read as overt attempts to push its quality standards at every opportunity in order to belittle competitors. As seen in Figure 8, Western Electric wanted Australians to believe that it made the 'dream' of projecting and amplifying the talkies a modern reality.

Australian systems had little choice but to imitate the capabilities of Western Electric equipment in order to project all types of Hollywood sound films. This strategy was known commonly as the 'interchangeability' factor, and was really about a system's perceived performance and service in a global context. Demanding quality from an alternative system was Western Electric's primary control device. Each sound company mentioned above had to be able to demonstrate - through trade screenings or through gaining Western Electric's approval and/or through a distributor's continuing contracts for films - that its equipment provided exhibitors with sound that was good enough to keep the patrons coming.

It seems that sound companies continually perfected their systems in this way throughout the transition to sound. The American RCA Photophone succeeded because, after July 1928, it and Western Electric had agreed to make their systems fully compatible. As a result, when RCA arrived in Australia in May 1929, the quality of its system had been accepted and endorsed by Western Electric for nearly a year. As seen in Figure 9, the RCA company promoted heavily its patented technology and aggressive service strategies. 


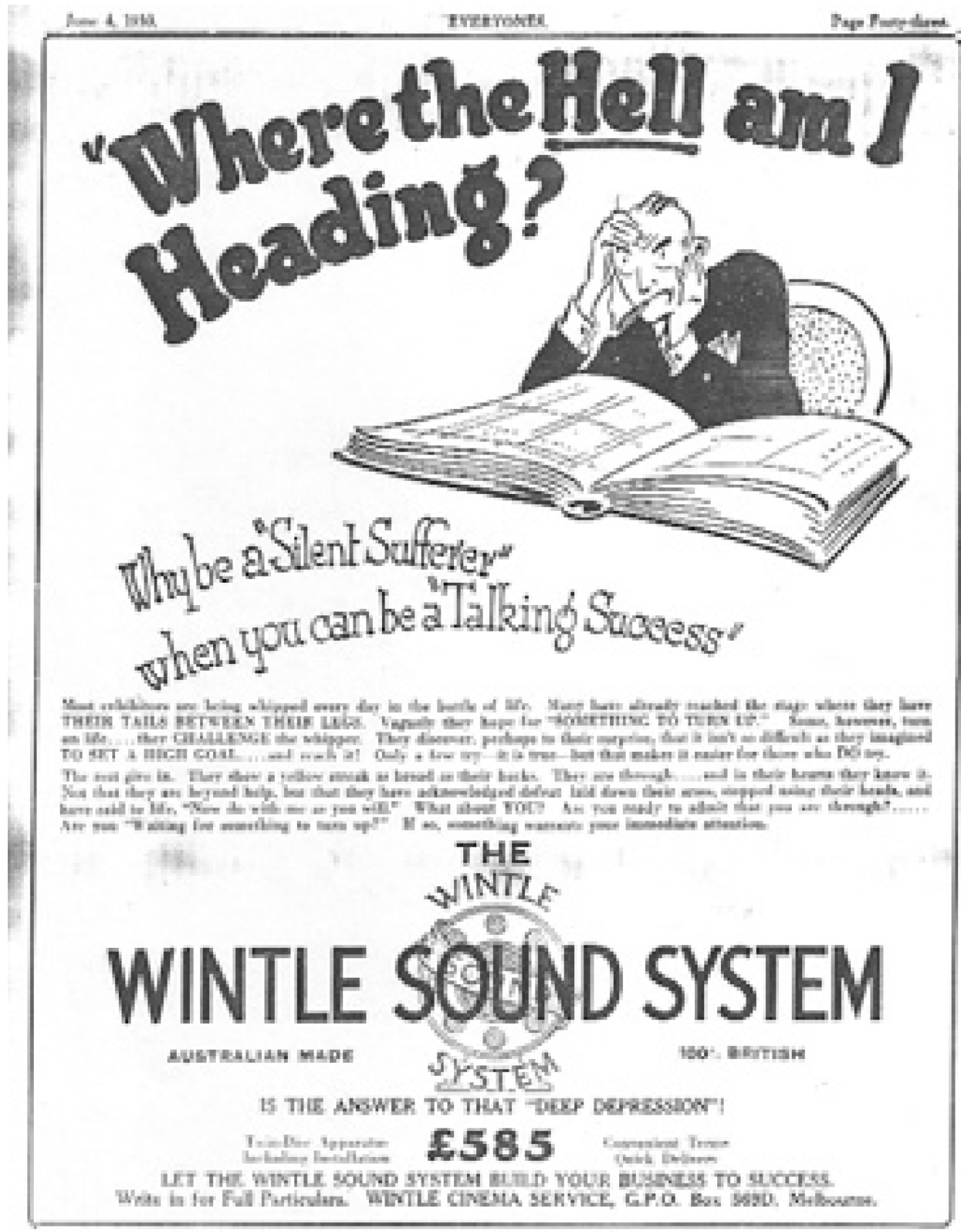

\section{Figure 7}

Source: Advertisement, Wintle Sound System, Everyones, 4 June 1930, p. 43. Reprinted by permission of the National Library of Australia. 


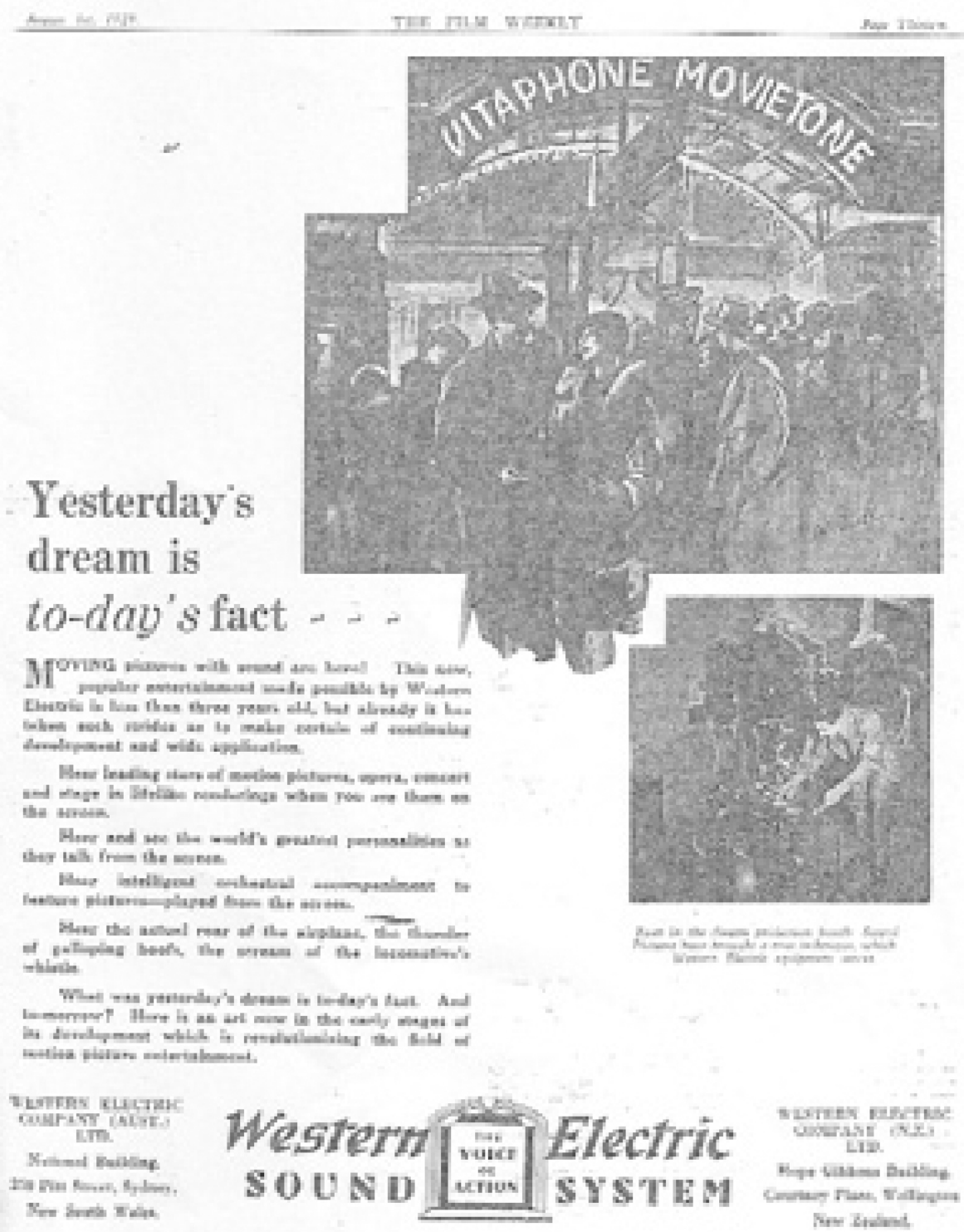

\section{Figure 8}

Source: Advertisement, Western Electric, Film Weekly, 1 August 1929, p. 13. Reprinted by permission of the National Library of Australia. 


\section{Derember 26rh. 1929. $\quad$ THE FLLM WEEKLY $\quad$ Poge Severnteen. \\ Proof of Efficiency and Service}

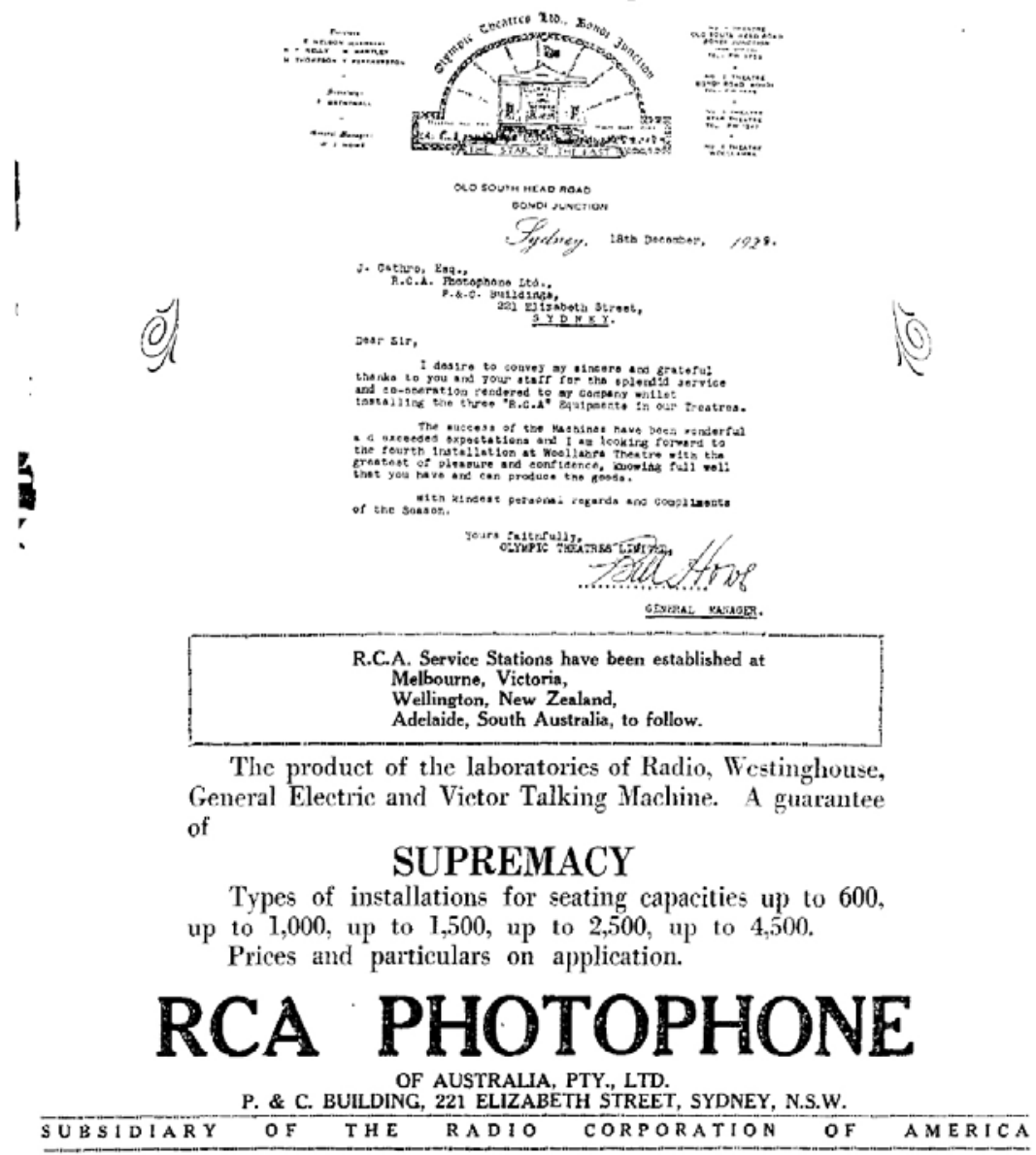

\section{Figure 9}

Source: Advertisement, RCA Photophone, Film Weekly, 26 December 1929, p. 17. Reprinted by permission of the National Library of Australia.

As we have seen, other systems, such as Australtone, were not as fortunate because they did not meet Western Electric's standards. Hence, a system's versatility (its ability to handle films recorded in the Movietone, Vitaphone and Photophone format) undoubtedly played a role in its success. ${ }^{60}$

\section{Conclusion: Australia's experience of modernity in sound}

The research in this chapter has attempted to show how the entrepreneurial ambitions of Australian sound companies and other individuals were part of 
Australia's experience of modernity. The coming of sound was influenced and shaped by a diverse group of Australians who at least pretended to be modern and/or understood the line of modernity brought by the prominent distribution of thousands of American (and European) sound films. Their individual and at times shared experiments with film sound represent a kind of fluid spirit that stirred in hegemonic responses to the demands of Hollywood. That is, Australians did whatever they could to innovate and adapt sound technology as well as to facilitate the exhibition of Australian sound films ${ }^{61}$ —all while trying to assess and manage the trade-offs between opportunity and risk. They were also caught between the promise of global modernity, collusion and the threat to national identity.

We can read their contributions as a complex combination of patriotism and conscientiousness, on the one hand, and a pragmatic and opportunistic spirit, on the other hand, which in due course enabled these representative Australians to join in the trajectory towards modernity. Whether they realised it or not, they were all agents of modernity, mediating complex social, cultural and technological changes in Australia, as were other pioneers delving into sound in other parts of the 'modern' world. Ultimately, most Australian systems and sound companies failed, but their reactions to the rhetoric of modernisation - or Americanisation - of the Australian film industry were significant in Australia's overall cultural and technological history. This is what makes the case of the coming of sound to Australia distinctive.

Evidence in the trade papers and archives suggests that the expression of Australia's modern consciousness rose partly in resistance to the 'American twang' and its potentially negative impact on Australian society. American twang was a popular expression found in major Melbourne newspapers while the talkie technology battle was taking place. During the mid-1920s and early 1930s, headlines such as 'American Films - Evil Effect on Young People', 62 'Bad English in "Talkies"-Rigid Censorship Advised", 33 'American "English"_-Impure Accent Feared", 64 “"American Twang"—Talking Pictures Criticised', 65 'Menace to Children' 66 and 'The Film Till Now-A Story of Americanization' riddled the popular press. ${ }^{67}$ I interpret these articles and anonymous editorials, which were supported with distribution and exhibition statistics, as partly the result of anti-American attitudes linked to the increased use of subtitles and intertitles in silent films.

Educators and empire loyalists saw Hollywood films and American culture in general as lowering moral standards in Australia. At the same time, they saw the adoption and diffusion of talkie technology as an opportunity to promote British culture and 'pure' English. ${ }^{68}$ Between 1929 and 1933, anxieties about potentially being Americanised surfaced in annual education conferences and teachers' union meetings. Parliamentary debates also included heated discussions 
on the topic. These anti-American feelings were real; however, the Federal Government and the national film censors could do little to stop the barrage of Hollywood films. Essentially, this was one of the lines of logic used to advocate for a stronger film industry throughout the Commonwealth.

In 1926, 83 per cent of films imported to Australia were from the United States, while only 7 per cent were from Britain. Hollywood's 'corrosive effect' led eventually to a Royal Commission in May 1927, which heard testimonies of thousands of witnesses from the film industry and the public, who pleaded with the Ministry of Trade and Customs to restrict the importation of US films. Increasing their tariffs, which potentially ensured fair competition, and lowering tariffs on British films were common requests. The Royal Commission lasted a year and concluded the obvious: there was an American stronghold on the film market in Australia. Little could be done, however, to reverse this trend-even after the emergence of permanent commercial talkies.

When scholars have written about sound, they have generalised and not considered the competition within Australia nor the diversity of the companies and individuals involved in the coming of the talkies. Australian sound companies, freelance inventors, backyard tinkerers, businessmen and manufacturers all challenged what appeared initially to be a dominant American influence on sound technology. Australians were as obsessed with modernity and sound's capabilities as pioneers across the globe. As seen in this chapter, individual and at times common efforts to modernise the Australian industry involved a series of proactive and reactive strategies, leading to a virtual war of words in the trade advertisements surrounding the plethora of wares heralded to the industry.

Clearly, this was a period in which 'locally made' was a sign of a complex collaboration among Australian business interests as the world changed because of ambivalence. One might say there was a battle for modernity and standardisation that Raycophone, Australtone, Markophone, Auditone and many other sound systems promoted in articles and advertisements in the popular and trade press during this time. These alternative systems helped wire thousands of cinemas in suburban and rural locations, which the big American electric firms could not reach or simply had no interest in reaching - symbiotically encouraged by exhibitors keen to explore the novelty and profitability of sound.

When left to their own devices, Australians helped create fertile ground for the exhibition and possibly the surprising success of domestic sound films. Raycophone, Australtone, Markophone and Auditone equipment fulfilled a demand for modern Australian sound technology while stimulating the rise of other systems functioning as alternatives to them and Western Electric. In these ways, Allsop, the Tighes, Snider, Betts and Noad as well as Ward and Hawkins acted as agents of modernity while their systems were indeed a kind of local 
means for exhibitors to participate in the modernisation of the domestic cinema. This small but energetic group exercised everything they could to be part of the sound revolution - namely, part of modernity and the changing audiovisual landscape of the metropolis.

There was something far more interesting happening during this period than a nation waiting to be 'awakened' by sound and Americans bringing new technology to a culture living in the dark ages. The coming of sound is as much a story about the embracing of ideas of urban modernity as it is about responding to the fears that empire loyalists, teachers, ministers, local officials and women's groups expressed against the possible side-effects US films might have on young Australians. It was partly these fears that developers of local, regional and national Australian sound systems exploited in order to gain as many installation contracts as possible.

There are many lessons that can be learned about maintaining a local presence in an incredibly 'global' world. In Australia's talkie war, American interests demonstrated and dictated where, when and how the battles would be fought. All the companies had to meet American terms or go down in defeat. Yet the war rhetoric ignores the fact that Raycophone (and others) did innovate, adopt, thrive and survive - not by defeating the Americans but by assimilating them, by making them Australian rather than shaping the Australian cinema in a solely American way.

\section{Acknowledgements}

Archival research was made possible through a URC-New Researcher Grant endorsed by the Faculty of Arts and the Centre for Asia Pacific Social Transformation Studies (CAPSTRANS) at the University of Wollongong. The author thanks the dedicated and very helpful archivists at the National Archives of Australia, National Library of Australia, National Film and Sound Archive, State Records of South Australia, NSW Public Records Office and Australian Patent Office in Canberra and Melbourne. Additional thanks go to Joy Damousi and Desley Deacon for extending an invitation to join this exciting project and to Kate Bowles and Chris Barker for their helpful feedback and continuing collegial support. An earlier version of this chapter appears as 'Projecting Sounds of Modernity: The rise of the local "talkie" technology in the Australian Cinema, 1924-32', Australian Historical Studies, vol. 35, no. 123, April 2004, pp. 54-83. 


\section{ENDNOTES}

${ }^{1}$ See Nowell-Smith, G. and S. Ricci 1998, Hollywood and Europe: Economics, Culture, National Identity, 1945-95, British Film Institute, London; Higson, A. and R. Maltby (eds) 1999, 'Film Europe' and 'Film America': Cinema, Commerce and Cultural Exchange, 1920-39, University of Exeter Press, Exeter.

2 Between June and July 1930, the German Tobis-Klangfilm and American Western Electric-ERPI and RCA Photophone firms assembled at the Paris Picture Sound Conference and deliberated on how to carve up global sales territories for their sound technologies. These particular big electric companies researched and developed sound applications in the first instance, providing essential manpower and hardware for the experimentation, diffusion and eventual wide-scale adoption of sound. The 'Paris Agreement', which was signed on the last day of this conference, divided the world into three sales zones: an exclusive German territory, an exclusive US territory (which included Australia and New Zealand) and a neutral territory. Detailed conference minutes are held in the Academy of the Motion Picture Arts and Sciences Library Archives, MPAA General Correspondence Files, MF Roll \#1, 1929-30.

3 'Sound projection technology' here refers specifically to the two basic film formats that dominated the US and European film industries at the time. Sound-on-disc systems used gears and chains to synchronise a phonograph (playing gramophone records) with an existing silent projector. Sound-on-film equipment used (microscope) lenses and special patented lamps to read and amplify audio signals, which appeared as sound waves along the edge of the film. Apparently, the tonal qualities of the disc format were superior to those of sound-on-film, however, discs often skipped and caused synchronisation problems. Sound companies continued to improve both formats in order to hedge their product lines (market share) if and when one method became the sole industry standard. Until about 1933 in Australia, disc systems were as popular as sound-on-film (or at least in the larger cinemas wired with dual systems - under pressure from Hollywood distributors - in order to maximise access to the widest number and types of sound films).

4 Western Electric opened offices in Sydney in January 1926 in order to 'modernise' Australia with American telephone and electrical technology. In early 1927, Western Electric's sales and service company, Electrical Research Products Inc. (ERPI), filed Australian patents for its 'Talking Motion Picture System', which offered sound-on-disc, sound-on-film or dual configurations. The company was ready to dominate the Australian cinema - as Australians would soon find out. See 'Western Electric Company (Australia) Pty Ltd Memorandum of Association and Special Resolution Adopting New Articles of Association, 11 January 1926', Defunct Company Records, File \#934-F2255, NSW Public Records Office, Sydney; and 'Electrical Research Products Inc., Application For Patent on Behalf of a Company as Assignee of the Actual Inventor, 18 May 1927', Public Inspection Correspondence Records, File \#7947/27, Australian Patent Office, Canberra.

5 Matthews, J. J. 2005, Dance Hall \& Picture Palace: Sydney's Romance With Modernity, Currency Press, Sydney, p. 15. Matthews offers a fascinating account of Australia's engagement with modernity between the economic recessions of the 1890s and the 1930s.

6 The only exception in the race to screen commercial talkies in Australia at the end of 1928 seems to have been a mobile disc system known as the Han-a-phone, which was imported from the United States and promoted as the 'latest marvel of the age' and 'leader of the new era of sound'. The licence-holders of the Han-a-phone targeted cinemas in country towns, although the project failed after mid-1929 due to difficulties finding trained operators. See Film Weekly, 8 November 1928, p. 8; and Film Weekly, 13 June 1929, p. 16.

${ }^{7}$ For the most part, Western Electric equipment was rented or licensed to exhibitors and cinema chains. Contracts were negotiated on an individual ad hoc basis in order to extract the highest potential revenues. Prices, if advertised at all, usually evaded the duty, transportation, maintenance and disc replacement costs, making this particular US technology cost prohibitive for most suburban showmen. See Everyones, 14 November 1928, p. 7. In June 1929, Film Weekly reported that the King's Cross cinema in Darlinghurst, Sydney, had installed Western Electric equipment at a rough cost of $£ 6,000$, though the company was promising to lower costs some time in the near future. See Film Weekly, 27 June 1929, p. 3.

8 See Gomery, D. 1980, 'Hollywood Converts to Sound: Chaos or Order?', in E. W. Cameron (ed.), Sound and the Cinema: The Coming of Sound to American Film, Redgrave, South Salem, New York, pp. 24-37; and Gomery, D. 1985, 'The Coming of Sound: Technological Change in the American Film Industry', in T. Balio (ed.), The American Film Industry, R evised edition, University of Wisconsin Press, Madison, pp. 229-51.

9 Along with the MPDA of Australia, the Film Renters' Association was dominated by American interests. All but one member of the association - Greater Australasian Films Ltd — worked for American 
distribution exchanges. See Tulloch, J. 1982, Australian Cinema: Industry, Narrative, and Meaning, George Allen and Unwin, Sydney.

10 Collins, D. 1987, Hollywood Down Under-Australians at the Movies: 1896 to the Present Day, Angus \& Robertson, North Ryde, NSW, p. 77.

11 'De Forest Phonofilms (Australia) Ltd Certificate of Incorporation and Memorandum and Articles of Association, 22 August 1925', Defunct Company Records, File \#9756, NSW Public Records Office, Sydney.

12 See, for instance, Film Weekly, 21 April 19 27, p. 13.

13 See Yecies, B. 2005 , 'Transformative Soundscapes: Innovating De Forest Phonofilms Talkies in Australia', Scope: An Online Journal of Film Studies, no. 1, available from www.nottingham.ac.uk/film/journal (accessed February 2005).

14 See Film Weekly, 8 June 1927, p. 9. All sound-on-film systems were seen as an infringement on De Forest's US patents. Exhibitors installing Western Electric (Fox Movietone) sound-on-film were directly implicated, though the Western Electric (Warner Vitaphone) disc system was not considered an infringement because it was significantly different to the Phonofilms format.

15 The warnings could have been a bluff because at the time the company's legal rights were still being decided in US courts. In any case, this was one of the only ways in which the Australian De Forest Phonofilms Company could protect its market share from competition because patent infringement suits were one of the legal weapons used to protect rights to collect royalties.

16 Everyones, 28 November 19 28, p. 7; Film Weekly, 29 November 1928, p. 10.

17 Everyones, 2 January 1929 , p. 6.

18 Everyones, 9 January 1929 , p. 4.

19 Everyones, 14 November 19 28, p. 7.

${ }^{20}$ Archival research indicates that installation contracts (also known as wiring contracts) were agreements that exhibitors and cinema owners made with sound companies and/or individual engineers to wire their cinemas with sound equipment. Contracts specified how a company would convert a cinema to sound, including the particular brands of sound equipment used and service and maintenance fees. See also Everyones, 8 May 19 29, p. 6; Everyones, 5 June 1929, p. 6; Argus, 5 July 1929, p. 11; Film Weekly, 11 July 1929 , p. 16.

21 See, for example, Harden, F. 1990, 'Timeline: 1895-1930', Cinema Papers, no. 78, pp. 20-5; Reade, E. 1975 , The Australian Screen, Lansdowne Press, Melbourne, p. 143; Allard, A. 1989, 'Grand Gala of Gab (1928-1939)', in I. Bertrand (ed.), Cinema in Australia: A Documentary History, University of New South Wales Press, Kensington, NSW, pp. 121-76; Stockbridge, S. 1979 'Monopoly Capitalism: T he Case of the Australian Film Industry', The Australian Journal of Screen Theory, v ols 5-6, pp. 17-35; Dermody, S. 1981, 'Rugged Individualists or Neocolonial Boys? The Early Sound Period in Australian Film, 1931/2', Occasional Papers in Media Studies - Faculty of Humanities and Social Sciences, New South Wales Institute of Technology, Broadway. Among these studies, few systems are named or credited for their part in trying to break the American monopoly - confirming Hollywood's dominance.

22 Shirley, G. and B. Adams 1989 , Australian Cinema: The First Eighty Years, Currency Press, Hong Kong, p. 104. The best known of these was Ray Allsop's Raycophone, but the Auditone system is mentioned in the two paragraphs dedicated to the Raycophone.

23 Tulloch, Australian Cinema, p. 17.

24 Walsh, M. 1999 , 'The Years of Living Dangerously: Sound Comes to Australia', in D. Verhoeven (ed.), Twin Peaks, Australian Catalogue Co., Melbourne, p. 69.

25 Ibid., p. 72.

26 Geduld, H. M. 1975 , The Birth of the Talkies: From Edison to Jolson, Indiana University Press, Bloomington, p. 252.

27 Film Weekly, 28 March 19 29, p. 10. The editors of Film Weekly proclaimed confidently that Allsop's system was 'no hot air'.

28 See 'Local Talkie Has Secret Try-Out', Everyones, 6 February 1929, p. 6; and 'Talking Films: New Australian Equipment, First Public Demonstration', Sydney Morning Herald, 11 June 1929, p. 15.

29 Film Weekly, 17 April 19 30, p. 36.

30 Everyones, 16 June 19 37, p. 4. 
31 Fascinating details concerning Allsop's invention can be found in the following archival documents: 'Raycophone Ltd', File \#17/8897-12589, NSW State Records, Kingswood, Sydney; and 'Raycophone Ltd', File \#A461/9-S301/1/3, Australian National Archives, Canberra.

32 Allsop, R. C. 1970, 'ABC Radio Interview-Transcript, Sydney, September 1970', in the Allsop Collection, National Library of Australia, Canberra, File\# MS 421, pp. 14- 15.

33 Ritchie, J. ( ed.) 1993, 'Allsop, Raymond Cottam', Australian Dictionary of Biography: A-De, vol. 13, 1940-80, Melbourne University Press, Melbourne, p. 38.

34 Everyones, 6 February 19 29, p. 6.

35 Everyones, 9 January 1929 , p. 4.

36 Everyones, 6 February 19 29, p. 7.

37 See Tulloch, Australian Cinema, p. 62. During this time, according to company records, John Tait was also a large shareholder in Australasian Films Ltd, which was managed by Stuart Doyle (File \#17-8851/4723, Australian Archives of NSW, Sydney). Hoyts Theatres' company records for this period also indicate that John Tait was on its board of directors with Frank Thring during the coming of sound (Hoyts File \#1 and 2, Melbourne University Archives).

38 Keith Murdoch's involvement in the motion picture industry continued while supporting Raycophone. In December 1932, Murdoch's Herald and Weekly Times financed Melbourne-based Australian Sound Films Ltd, which was established to make news-reel films exclusively for Murdoch's growing newspaper empire. See Everyones, 14 October 1931, p. 9.

39 'Australian Synchronised Sound Pictures Ltd Memorandum and Articles of Association, 31 August 1929', Defunct Company Records, File \#10515/7551, NSW Public Records Office, Sydney.

40 Everyones, 31 July 19 29, p. 6.

41 Australtone's locally made sound films included songs, violin solos, comedy acts and pianoforte selections performed by Fred Bluett, Hector St Clair, Mabel Barham, Les Rohmer and Bert Corrie. Higgins used recording equipment belonging to the Tighes to shoot the shorts in the Lecture Hall of the Royal Sydney Show Grounds, where the Tighes had constructed a small studio for local productions. The synchronised discs were then pressed by Broadcasters Ltd, Melbourne, which was affiliated with the Sydney company that Allsop worked with. See Film Weekly, 18 July 1929, p. 3; and Film Weekly, 8 August 19 29, p. 12.

42 Everyones, 9 October 1929 , p. 21.

43 In comparison, Queensland cinemas had 106 dual and 12 disc-only projectors. Victoria and NSW had the highest number of cinemas wired for sound - most of which were dual projectors. Western Electric and Raycophone made most of the installations in NSW - therefore, cinemas in NSW experienced the most pressure to adopt alternative sound systems that emulated standards set by Western Electric and Raycophone. See Everyones, 10 December 1930, p. 14.

44 Film Weekly, 8 August 1929 , p. 21.

45 As early as 1918, E. L. Betts believed strongly in marrying 'appropriate and well played' music with pictures in order to create a film's full effect. See Theatre Magazine, 1 February 19 18, pp. 33-4.

46 Hoyts Theatres' executives created this company to offer its large exhibition chain a cheaper way to wire the majority of its smaller suburban and country cinemas outside Hoyts Theatres' contracts with Western Electric. See 'Markophone Ltd Memorandum and Articles of Association, 3 February 1930', Defunct Company Records, File \#17/5742-13203, NSW Public Records Office, Sydney.

47 'Auditone Ltd Memorandum and Articles of Association, 28 October 1929' , Defunct Company Records, File \#17/5726-12888, NSW Public Records Office, Sydney.

48 Between 1922 and 19 26, Hawkins was a producer with Sydney-based Sovereign Pictures, where he made educational, scientific and industry films for the NSW government and commercial organisations. He joined Phonofilms Australia when it merged with Sovereign Pictures. See Everyones, 8 December 1926, p. 18; and Hawkins, Stanley W. 1927, 'Interview with Walter M. Marks', Report of the Royal Commission on the Moving Picture Industry in Australia, The Parliament of the Commonwealth of Australia, Canberra, 29 July 1927, pp. 413-21.

49 In August 1929, Broadway Theatres Ltd removed Auditone systems from two of its theatres and cancelled pending installation contracts. The company then installed Western Electric equipment at its Acme Theatre. Thus, Western Electric-ERPI had successfully sold its equipment to one of the largest investors and supporters of the Auditone system, and Auditone became one of the systems that exhibitors were throwing on the scrap heap, which Western Electric's advertisements exploited. See Film Weekly, 15 August 1929, p. 18; Everyones, 11 June 1930, p. 13; and Film Weekly, 3 March 1932, p. 32. 
50 Lumenthode and Ward Sound were still operating in mid-1933, however, by 1936, all of the sound companies that Ward and Hawkins had been associated with had ceased to be recognised in Film Weekly's 'Who's Who' supplement list of 'Sound Equipment Companies Operating in Australia' (24 September 19 36, p. 28). A majority of Australia's cinemas had been wired by this time, and few new installations were needed.

51 Everyones, 16 June 19 37, p. 4.

52 Film Weekly, 10 January 19 29, p. 16.

53 Everyones, 4 June 1930, p. 43.

54 Everyones, 26 November 19 30, p. 47.

55 Everyones, 11 December 19 29, p. 106.

56 Everyones, 7 August 19 29, p. 21.

57 Film Weekly, 25 August 19 32, p. 19.

58 Everyones, 21 May 1930, p. 21.

59 Film Weekly, 17 April 19 30, p. 36.

60 Service was part of a sound company's ability to deliver a quality product as well as its appeal to exhibitors. Western Electric and RCA established service centres throughout Australia in order to better provide clients with general maintenance and equipment upgrades. Western Electric's mandatory 10-year fee-based service contracts meant, however, that local companies that did not demand a service contract could gain a market advantage. RCA most likely became a popular alternative American system - at least in the Australian market - because it offered a free service plan. Furthermore, companies such as Markophone, which promoted its 'foolproof' equipment, also appeared popular initially with exhibitors who did not want to worry about expensive and time-consuming repairs.

61 According to Film Weekly, 58 Australian films were produced and released commercially between 1930 and 1939. See the 'Film Weekly Motion Picture Directory, History of Australian Production', Film Weekly, 1969-70, Sydney, pp. 67-72.

62 Argus, 14 June 1926, p. 10.

63 Argus, 11 June 1929, p. 11.

64 Argus, 7 August 1929, p. 7.

65 Argus, 31 October 1929, p. 8

66 Argus, 15 April 1930, p. 9.

67 Argus, 18 October 1930, p. 6.

68 In June 1926, legislators in Victoria commented that the amount of American films coming into Australia was acting to the detriment of the British Empire and was having an ill effect on the young people of Australia'. See Argus, 14 June 1926, p. 10. In the same month, after returning from an education conference in Canada, the Australian Director of Education, S. H. Smith, claimed that 'we need legislation to enable our censors to exclude all talking pictures which disregard the cannons of pure speech as practiced amongst the educated classes in British communities'. See Sydney Morning Herald, 10 June 1929, p. 11. 